European Journal of Accounting, Auditing and Finance Research

Vol.8, No. 6, pp.15-27, May 2020

Published by ECRTD-UK

Print ISSN: 2053-4086(Print), Online ISSN: 2053-4094(Online)

\title{
EFFECT OF DIVIDEND POLICY ON SHAREHOLDERS WEALTH IN NIGERIA (1986 TO 2016)
}

\author{
Lucky Ejieh. Ujuju \\ Department Of Banking/Finance,Delta State Polytechnic, Ozoro, Delta State \\ Phone No: 08023261780 \\ E-mail: Ujujulucky2004@Yahoo.Com \\ 2 Julius Ovuefeyen Edore \\ Department Of Banking/Finance, Delta State Polytechnic, Ozoro, Delta State \\ Phone No: 09095799524, 08076340974 \\ E-mail: Juliusedora@Gmail.Com
}

\begin{abstract}
S: This study investigated the effect of dividend policy on shareholders wealth in Nigeria. Data were generated on market price per share (MPS), dividend per share (DPS), net asset per share (NAPS) and earnings per share (EPS) from annual report and accounts of twenty five quoted companies in Nigeria stock exchange (NSE) Fact book and daily official list. To analyze the data, the statistical tools that have been used are ordinary least square regressions $(O L S)$, unit root tests, Johansen cointegration and error correction model (ECM) for predicting the dividend policy effect on shareholder's wealth. The significance of the various explanatory variables has been tested by computing t-values. To determine the proportion of explained variation in the dependent variable, the coefficient of determination $\left(R^{2}\right)$ has been worked out. The significance of $R^{2}$ has also been tested with the help of $F$-value. The results show that most of the variable except dividend per share had significant relationship with market price per share. The $R^{2}$ and $F$-test shows that earnings, dividend and net assets has combined effect on market price of shares but none of these variables has direct independent influence in determining the price of share in the stock market. This paper, therefore conclude that dividend payout does not have effect on shareholders wealth and shareholders do not react to dividend information. It was therefore recommended that firms operating under this environment should ignore distribution of earning and concentrate with investments that will boost net assets.
\end{abstract}

KEYWORDS: dividend policy, shareholders' wealth, Nigeria

\section{INTRODUCTION}

\section{Background to the Study}

Numerous literatures abound on the relevance of dividend policy on financial decisions of firms. This value-relevance proposition of dividend policy has been in the forefront of financial research since Miller and Modigliani’s (1961) pioneering work (Travlos, Trigerorgis and Vafeas, 2001; and Nnadi and Akpomi, 2008). The Miller-Modigliani's work argue that, in a perfect world, the value 
European Journal of Accounting, Auditing and Finance Research

Vol.8, No. 6, pp.15-27, May 2020

Published by ECRTD-UK

Print ISSN: 2053-4086(Print), Online ISSN: 2053-4094(Online)

of the firm is unaffected by its dividend decisions, so there should not be any wealth effect upon the announcement of a change in dividend payout policy.

But it is well known that stock prices generally move in the direction of the dividend change (Ryan, Besley and Lee, 2000). This supports Kouki's (2009) assertion that "explaining dividend policy has been considered as one of the most difficult controversies of the three issues of long term financial decisions making." Despite the numerous published theoretical and empirical studies, we are yet to understand completely the factors that explain the firm payout policy. The usefulness and justification of the dividend policy therefore constitutes one of the most debated topics of the financial theory (Romon, www.institute -europlace.com). Fletcher and Scholes (1974) wrote that "... the harder we look at the dividend picture, the more it seems like a puzzles don't fit together". A number of researches provide theoretical as well as empirical evidence on different aspects of dividend policy but a lot of issues are still unresolved (Aboody and Kasznik, 2001). Among these are issues related to wealth effect of dividend payouts and the explanations on them.

A good number of empirical works have tried to explain this value-relevance nexus for the dividend policy. Bhattacharya (1998), and Miller and Rock (1985) posit the presence of signaling effect hypothesis, that is there exists asymmetric information between managers and shareholders as the factor that brought about the effect of dividend policy on financial decisions. Jenson's (1986) Free Cash Flow (FCF), in their agency theory also known as overinvestment hypothesis provided an alternative explanation for this positive relationship between the direction of the dividend change and the stock price reactions, other hypotheses include the Dividend Clientele hypothesis which explains the effect of ownership concentration and tax payout ratio on dividend policy.

\section{Statement of the Problem}

There have been mixed results from numerous researches conducted on the effect of dividend policy on shareholders wealth not only in Nigeria but also in the rest of the world which had generated mixed findings. Azhagaiah \& Priya (2008) conducted study on the impact of dividend policy on shareholder wealth in South India. Secondary data used where collected from center for monitoring India economy. Sample of 28 companies in chemical industry has been chosen from 114 listed companies in Bombay stock exchange using multi stage random sampling techniques for period of 1997 to 2006 . Multiple regression \& stepwise regression model used for data analysis. Dividend per share, retained earnings per share, lagged price earnings ratio \& lagged market price independent variables \& market price per share dependent variable. There is a significant impact of dividend policy on shareholder wealth in organic chemical companies while shareholders wealth was not influence by dividend payout as for as inorganic chemical companies.

Mokaya, Nyang'ara \& James (2013) explains how dividend policy effect market share price in banking industry of Kenya. This study covered the sample of 100 respondents represented a population of 47000 general public shareholders questioners were used to collect the data. Market share value is the dependent variable and dividend policy is the independent variable. Descriptive and inferential statistics were used to determine and explain variable's relationships. The study concluded that National Bank of Kenya had a dividend policy and this dividend policy is the major 
European Journal of Accounting, Auditing and Finance Research

Vol.8, No. 6, pp.15-27, May 2020

Published by ECRTD-UK

Print ISSN: 2053-4086(Print), Online ISSN: 2053-4094(Online)

factor driving NBK share value. It has been seen that an increase in dividend payout may result an increase in share price.

Besides these positive conclusions, Khan and Khan (2011) conducted research on dividend policy and its effect on shareholders wealth. The purpose of the study is to determine the factors of dividend policy that affect the shareholders wealth. The sample in this study is 131 companies listed at Karachi Stock Exchange for a period of 10 years from 2001 to 2010. Panel data approach is used to measure the relation between dividend policy and shareholders wealth. In this study price volatility is taken as dependent variable which is calculated by using Parkinson method of extreme values. Retention ratio, stock dividend per share, earning per share, net profit after tax and return on equity are used as independent variables to study the effect of stock prices. The results of this study showed that the stock dividend, earnings per share, profit after tax, and return on equity has negative effect on stock prices and retention ratio has negative effect on stock prices. Overall concluded in this study is that dividend policy has insignificant negative effect on stock prices. In the light of these mixed results and findings, this paper aimed at demonstrating a clearer analysis on the effect of dividend policy on shareholders wealth in Nigeria in other to fill the gap in literature thereby contributing to knowledge.

\section{Objectives of the Study}

The main objective of the study was to examine the effect of dividend policy on shareholders wealth. The specific objectives include:

1. To determine the effect of dividend policy on shareholders wealth.

2. To examine the effect of dividend per share on shareholder wealth.

3. To investigate the effect of earning per share on shareholders wealth.

4. To determine the effect of net asset per share on shareholders wealth.

\section{Research Hypotheses}

The following tentative statements were formulated to guide this study.

$\mathrm{Ho}_{1}$ : Dividend policy does not have significant effect on shareholders wealth.

$\mathrm{Ho}_{2}$ : dividend per share does not have significant effect on shareholder wealth.

$\mathrm{Ho}_{3}$ : Earning per share does not have significant effect on shareholders wealth.

Ho4: Net asset per share does not have significant effect on shareholders wealth.

\section{REVIEW OF RELATED LITERATURE}

\section{Conceptual Framework}

Dividend is the distribution of value to shareholders (Tajirian, 1997). This can be in the form of (i) Cash dividends - where cash is distributed to the shareholders. These dividends are paid out of Treasury stock; (iii) Stock split - Similar to a stock dividend only that existing shareholding are split into more share, say (2-1 split), i.e., for every share you own, now you own two. This is usually to make stock "more attractive" to investors though the value of firm is not expected to change (Tajirian, 197); (iv) Share repurchases - The Company repurchases the stock. This study is concerned with cash dividend since it is the aspect of dividend that constitutes distribution of profit to shareholders. 
Dividends are usually paid to owners or shareholders of business at specific periods. This is apparently based on the declared earning of the company and the recommendations made by its directors. Thus, if there are no profits made, dividends are not declared (Nnadi \& Akpomi, 2008). When a dividend has been declared, it becomes a debt of the firm and cannot be rescinded. Declaration of dividend affects share prices of firms (Robert H. Smit). Dividend policy is what happens to the value of the firm as dividend is increased, holding everything else (capital budgets, borrowing) constant. Thus, it is a trade-off between retained earnings on one hand, and distributing cash or securities on the other (Tajirian, 1997 and Nnadi and Akpomi, 2008).

Some firms may have low dividend payout because management is optimistic about the firm's future and therefore wishes to retain their earnings for further expansion (Nnadi and Akpomi, 20080. Where a company retains most of its earnings, its expansion is enhanced but the market price of its shares will be relatively low. Others would maintain a generous dividend policy which keeps the market price of their shares high but at the expense of expansion, where there is no other source of capital (Igben, 1999).

Shareholders' wealth is represented in the market price of the company's common stock, which, in turn, is the function of the company's investment, financing and dividend decision (Van Horne \& Wachowicz, 2001). Managements' primary goal is shareholders' wealth maximization, which translates into maximizing the value of the company as measured by the price of the company's common stock (Shim and Siegel, www.Netlibrary.com). Shareholders like cash dividends, but they also like the growth in earning per share that result from ploughing earning back into the business (Khan and Jain, 1992). Earnings per share increases, thus value of firm increases (Tajirian, 1997).

\section{Theoretical Framework}

This work is anchored on signaling effect based on Modigliani and Miller (1961). This theory argued that dividend may have a signaling effect. It helps management to forecast on the future earning or long term planning of the company. Investor can predict the changes of future profit prospect for the firm based on the changes on the dividend rate. However, the firms must have stabilized dividend payout and higher dividend payout compared to target payout ratio. Dividend changes might not the causal factor to changes of share price. Nevertheless, changes on share price may reflect the future earning and opportunity cost for the respective company. In line with the study of Modigliani and Miller (1961), investors and management have asymmetric information. This leads to management tend to pass on the favorable information to the investors. However, low firm value's company may suffer higher cost in conveying information to investors as compared to high firm value's company.

\section{Empirical Review}

Several studies carried out on dividend policy (DP) and shareholders' wealth (SW) in the developed and developing countries. Salman (2013) examined the "Effect of DP on SW of sugar industry in Pakistan" considering a sample of 33 listed firms of sugar industry listed on Karachi Stock Exchange. The data were collected for a period of six years ranging from 2006 to 2011. 
Descriptive statistics and regression analysis were applied for analysis considering dividend per share (DPS), earnings per share(EPS), lagged market price per share (MPS), price earnings ratio (PER), and retained earnings (RE) as predictor variables and market price per share (MPS) as response variable. The study showed that DPS, EPS, Lagged MPS, and Lagged PER had significant positive relationship with SW.

Bawa and Kaur (2013), in a research work titled "Impact of dividend policy on shareholders' wealth: An empirical analysis of Indian information technology sector" selected 308 firms , which have listing flag in National stock exchange and Bombay stock exchange with the objective to study the impact of DP on SW. Variables, viz., dividend per share (DPS),retained earnings per share (REPS), lagged price earnings ratio (LAGPER) and lagged market price per share (LAGMPS) were considered as predictor variables and market price per share (MPS) was considered as response variable. Panel data methodology was applied to study the impact of DP on market value of equity. The results showed that in the long run, shareholders' wealth of dividend paying IT firms had increased significantly when compared to the non-dividend paying IT firms. Tahir and Raja (2014), in their study titled "Impact of dividend policy on shareholders' wealth" of oil and gas exploration firms of Pakistan during the years from 1999 to 2006 used regression and correlation to ascertain the best fitted model for the DP and to study its impact on SW. The variables viz., dividend payout ratio (DPR), price earnings ratio (PER) and book value to market value of equity (BV/MV) ratio were considered as predictor variables and holding period yield as response variable. The result showed a correlation between predictor variables and response variable for all the firms. Oil and gas industry of Pakistan paid dividend on regular basis but there was uncertainty in stock market due to which holding period returns were not efficient because share price of firms were not stable and fluctuation took place in firms and the study proved that dividend payout ratio had insignificant relationship with holding period yield.

Kumaresan (2014), in a study titled "Impact of dividend policy on shareholders' wealth: A study of listed firms in hotels and travels sector of Sri Lanka" focused on top ten firms under hotel and travel sectors in Sri Lanka during the period from 2008 to 2012. Shareholders' wealth (EPS) was considered as response variable while predictor variables were: return on equity (ROE), dividend payout ratio (DPR), dividend per share (DPS) and retention ratio (RR). The study used correlation and regression to analyse the data collected from top ten listed firms under hotel and travel sectors. The study found that there was a positive relationship between return on equity (ROE), dividend per share (DPS) and dividend payout ratio (DPO) and shareholders' wealth (SW) of the selected firms under hotel and travel sectors in Sri Lanka and the study also proved that there was a negative relationship between retention ratio and shareholders' wealth.

\section{METHODOLOGY}

\section{Research Design}

The study will adopt an ex-post facto research design. Time series data that covers twenty five quoted companies in Nigeria was collected from the Nigeria stock exchange (NSE) Fact book and daily official. 
Print ISSN: 2053-4086(Print), Online ISSN: 2053-4094(Online)

\section{Nature and Sources of Data}

The study will use secondary data that will be sourced from financial publications such as the Nigeria stock exchange (NSE) Fact book and daily official list, Federal Office of Statistics (FOS) for the study. The variables which the researcher intends to use include; Market price per share (MPS) which is the dependent variable and dividend per share (DPS), Earnings per share (EPS) and Net assets per share (NAPS) are the independent variables.

\section{Model Specifications}

The equations and variables used for the study given below are adaptation and modifications from the work of Azhagaiah \& Sabari, (2008) done in India. Azhagaiah and Sabari studied the impact of dividend policy on shareholders' wealth in India. This study then tested this model in Nigeria.

The model is stated thus:

MPS $=f(D P S, E P S$, NAPS $)$

Where,

MPS = Market price per share

DPS $=$ Dividend per share

EPS $=$ Earnings per Share

NAPS $=$ Net Asset per Share

$\beta_{0}$ and $\mu$ are the constant and error term respectively while $\beta_{1}$ and $\beta_{2}$ are the coefficient of dividend policy on shareholders wealth in Nigeria.

The equation form of the model is:

MPS $=\beta_{0}+\beta_{1}$ DPS $+\beta 2$ EPS $\beta 3$ NAPS $+\mu$

Where: $\beta_{0}$ and $\mu$ are the constant and error term respectively while $\beta_{1}$ and $\beta_{2}$ and $\beta_{3}$ are the coefficients of Dividend per share, Earnings per share and Net asset per share respectively.

\section{METHOD OF ANALYSES}

To analyze the data, the statistical tools that have been used are the ordinary least square regressions $(O L S)$, unit root tests, Johansen cointegration and error correction model (ECM )for predicting the dividend policy effect on shareholder's wealth. The significance of various explanatory variables has been tested by computing t-values. To determine the proportion of explained variation in the dependent variable, the coefficient of determination $\mathrm{R}^{2}$ has been worked out. The significance of R2 has also been tested with the help of F-Value. 
European Journal of Accounting, Auditing and Finance Research

Vol.8, No. 6, pp.15-27, May 2020

Published by ECRTD-UK

Print ISSN: 2053-4086(Print), Online ISSN: 2053-4094(Online)

\section{DATA PRESENTATION AND ANALYSIS}

Descriptive Statistics

Table4. 1: The Descriptive Statistics

\begin{tabular}{lllll}
\hline & MPS & DPS & EPS & NAPS \\
\hline Mean & 5.138190 & 75.68479 & 6.587155 & 13.18276 \\
Median & 4.887400 & 78.48770 & 4.076800 & 13.70000 \\
Maximum & 33.73580 & 228.6423 & 20.85860 & 14.20000 \\
Minimum & -10.75170 & 2.062700 & 0.076600 & 8.600000 \\
Std. Dev. & 7.704120 & 64.03453 & 6.478485 & 1.345381 \\
Skewness & 1.442398 & 0.505305 & 0.679157 & -2.375729 \\
Kurtosis & 8.342689 & 2.614791 & 2.137857 & 7.447787 \\
Jarque-Bera & 44.54687 & 1.413411 & 3.127540 & 51.18399 \\
Probability & 0.000000 & 0.493267 & 0.209345 & 0.000000 \\
Sum & 149.0075 & 2194.859 & 191.0275 & 382.3000 \\
Sum Sq. Dev. & 1661.897 & 114811.8 & 1175.182 & 50.68137 \\
Observations & 29 & 29 & 29 & 29 \\
\hline
\end{tabular}

The variables of the study shown on Table 4.1 above indicates that earnings per share (EPS) has mean of $6.58 \%$ with minimum and maximum values of $4.07 \%$ and $20.85 \%$ respectively. However, the standard deviation is $6.47 \%$ indicating high variation in the earnings per share (EPS) in Nigerian economy. This means that the Nigerian financial market is relatively unpredictable and risky. This is capable of discouraging investment in the financial market.

Again, the ratio of dividend per share (DPS) measures the extent to which total dividend per share can be deployed to determine the market price per share (MPS). A high or increasing ratio will indicate problems of dividend policy. From the result, it can be seen that DPS is $75.68 \%$. This suggests that $76 \%$ of the changes in market price per share (MPS) is accounted for by variations in dividend per share (DPS).

\section{Unit Root Tests Results}

It is almost a convention in time series analysis, to verify the order of integration for each series to avoid the problem of spurious regression (see Granger and Newbold, 1974; Phillips, 1986). The enquiry into stationarity property of each variable is conducted using Augmented Dickey-Fuller (Dickey and Fuller, 1979) and Phillips-Perron (Phillips and Perron, 1988) test procedures. The Phillips-Perron test method which computes a residual variance that is robust to auto-correlation is employed as alternative to the ADF. The decision rule is that Augmented Dickey Fuller (ADF) test statistics must be greater than Mackinnon Critical Value at 5\% and at absolute term, i.e. ignoring the negative value of both the ADF test statistics and Mackinnon critical values, before the variable is adjudged to be stationary, otherwise we accept the null hypothesis (Ho) that data is nonstationary and reject the alternate hypothesis (H1) that data is stationary. 
European Journal of Accounting, Auditing and Finance Research

Vol.8, No. 6, pp.15-27, May 2020

Published by ECRTD-UK

Print ISSN: 2053-4086(Print), Online ISSN: 2053-4094(Online)

Table 4.2 Result of ADF Unit Root Test

\begin{tabular}{lllll}
\hline Variables & $\begin{array}{l}\text { ADF } \\
\text { Statistics } \\
\text { Value }\end{array}$ & $\begin{array}{l}\text { 5\% McKinnon } \\
\text { Critical Value }\end{array}$ & $\begin{array}{l}\text { Decision } \\
\text { Rule } \\
\text { HI }\end{array}$ & Remarks \\
\hline MPS & -2.675452 & -3.0114 & Reject & Non-stationary \\
ROCE & 1.887654 & -3.0113 & Reject & Non-stationary \\
EPS & -2.322456 & -3.0113 & Reject & Non-stationary \\
NAPS & -2.735910 & -3.1310 & Reject & Non-stationary \\
DPS & -2.245702 & -3.0113 & Reject & Non-stationary \\
\hline
\end{tabular}

Source: Author's computation

From the result in table 4.2 it is clear that all the variables have ADF test statistics value less than the Mackinnon critical value both in absolute terms and at 5\% level - that is before differencing. Therefore, to ensure the stationarity of data for these variables, there is need to further test for stationarity at first difference. The result of first difference ADF unit root test is presented below:

Table 4.3

\begin{tabular}{lllll}
\hline Variables & $\begin{array}{l}\text { ADF Test Statistics } \\
\text { Value }\end{array}$ & $\begin{array}{l}\text { 5\% McKinnon } \\
\text { Critical Value }\end{array}$ & $\begin{array}{l}\text { Decision Rule } \\
\text { HI }\end{array}$ & Remarks \\
\hline MPS & -3.345776 & -.0199 & Accept & stationary \\
NAPS & -4.23054 & -3.0199 & Accept & stationary \\
EPS & -4.65789 & -3.0199 & Accept & Stationary \\
& & & & \\
DPS & -4.33217 & -3.0199 & Accept & stationary \\
\hline
\end{tabular}

Source: Author's computation

From the result in table 4.3, it could be seen that all the variables were stationary at first difference. We therefore reject null hypothesis because their respective ADF test statistics value is greater than MacKinnon critical value at both in absolute terms and at $5 \%$. The order of integration for all the variables is therefore is $1(1)$.

\begin{tabular}{ll}
$\begin{array}{ll}\text { Summary of Order of Integration } \\
\text { Variable }\end{array}$ & Order of Integration \\
\hline MPS & $1(1)$ \\
NAPS & $1(1)$ \\
EPS & $1(1)$ \\
& $1(1)$ \\
\hline
\end{tabular}

\section{Testing for Co integration}

With the results of the above unit-root tests suggesting that all the variables are stationary of the order 1(1), we move a step further to employ the Johansen (1991) and Johansen and Juselius (1990) procedures to test for co-integration among the variables. The Johansen methodology is a 
European Journal of Accounting, Auditing and Finance Research

Vol.8, No. 6, pp.15-27, May 2020

Published by ECRTD-UK

Print ISSN: 2053-4086(Print), Online ISSN: 2053-4094(Online)

generalization of the Dickey-Fuller test. Two likelihood ratio tests (trace and maximum eigenvalue) were used to test the hypotheses regarding the number of co integrating vectors.

Table 4.4 Result of Johansen Co-integration

\begin{tabular}{|c|c|c|c|c|c|c|}
\hline Eigen Value & Likelihood ratio & $\begin{array}{l}5 \% \\
\text { value }\end{array}$ & Critical & $\begin{array}{l}1 \% \\
\text { value }\end{array}$ & Critical & $\begin{array}{l}\text { Hypothesized } \\
\text { No. of CE(s) }\end{array}$ \\
\hline 0.925435 & 124.3875 & 92.18 & & 101.09 & & None** \\
\hline 0.502314 & 18.57445 & 27.34 & & 34.02 & & At most $2 *$ \\
\hline 0.233457 & 6.543293 & 16.90 & & 20.87 & & At most $3^{*}$ \\
\hline 0.012341 & 0.387546 & 3.55 & & 6.89 & & At most $4 *$ \\
\hline
\end{tabular}

$*(* *)$ denotes rejection of the hypothesis at $5 \%(1 \%)$ significance level

L.R test indicates 2 co-integrating equation(s) at 5\% significance level

Source: Author's computation

The result of the Johansen co-integration shows that co-integration (long run relationship) exist among the dependent variable -MPS and independent variables - Net asset per share, earnings per share and dividend per share on shareholders wealth. This can be inferred from the fact that the critical value at $5 \%$ is less than likelihood ratio. We therefore, reject the hypothesis of no cointegration at $5 \%$ significance level.

\section{The Ordinary Least Square Regressions}

In this section, we will test the significance of the independent variables in explaining the effect of dividend policy on shareholders wealth in Nigeria

Table 4.5 Ordinary Least Square Regressions

\begin{tabular}{lllll}
\hline Variable & Coefficient & Std. Error & t-Statistic & Prob. \\
\hline MPS & 15.73210 & 5.435635 & 1.543973 & 0.0003 \\
NAPS & 1.668951 & 0.991508 & -1.683245 & 0.1181 \\
EPS & 1.342700 & -0.099069 & 1.339468 & 0.2052 \\
DPS & -0.145270 & -0.695746 & 0.208798 & 0.8381 \\
R-squared & 0.909033 & Mean dependent var & 6.897917 \\
Adjusted R-squared & 0.898550 & S.D. dependent var & 1.094669 \\
S.E. of regression & 0.601022 & Akaike info criterion & 2.096940 \\
Sum squared resid & 4.334733 & Schwarz criterion & 2.444891 \\
Log likelihood & -12.92093 & F-statistic & 7.951898 \\
Durbin-Watson stat & 1.068708 & Prob(F-statistic) & 0.001265 \\
\hline Computed
\end{tabular}

Computed by the Authors with E-View Software

From the above regression coefficients, we can express the model (short-run) as follows:

$\mathrm{MPS}=15.73210+1.1668951 \mathrm{NAPS}+1.342700 \mathrm{EPS}-0.145470 \mathrm{DPS}+\mathrm{e}$

From the results of the OLS, it is obvious that the constant parameter (Bo) is positive at +15.73210 .

This means that if all the independent variables are held constant, MPS as a dependent variable will grow by 15.73210 units in annual-wide basis. 
European Journal of Accounting, Auditing and Finance Research

Vol.8, No. 6, pp.15-27, May 2020

Published by ECRTD-UK

Print ISSN: 2053-4086(Print), Online ISSN: 2053-4094(Online)

For return on capital employed, the coefficient of NAPS is +1.668951 . This means that there is positive relationship between net asset per share and MPS. In the short run, a unit increase in net asset per share (NAPS) will cause MPS to increase by 1.668951 units. The coefficient of earnings per share (EPS) is positive at +1.342700 . This means that there is a positive relationship between earnings per share (EPS) and MPS. A unit increase in earnings per share will lead to a unit increase in MPS by 1.342700 . This result is in line with a priori expectation.

Finally, the coefficient of dividend per share (DPS) is negative at -0.145270 . This means that in the short run, dividend per share (DPS) is inversely related to MPS. A unit increase in dividend per share (DPS) will lead to a decrease in MPS by 0.145270 units.

This result is contrary to the priori expectation. Above all, the coefficient of multiple determinations, denoted as (R2) is 0.909033 or approximately $91 \%$. This means that $91 \%$ of total variation in MPS can be explained by the exogenous variables namely NAPS, EPS and DPS while the remaining 9\% is due to other stochastic variables. The Durbin-Watson statistics (at1.068708) is below the critical threshold; this means the model is free from autocorrelation.

\section{SUMMARY, CONCLUSION AND RECOMMENDATIONS}

\section{Summary of the study}

This study used a time series data to investigate the effect of dividend policy on shareholders wealth in Nigeria between 1984 and 2014. The study employed Ordinary least square method and the Johansen Cointegration technique to ascertain the long run effect of the independent or explanatory variables (X) Dividend per share, Net asset per share and Earnings per share on share holder's wealth which is peroxide by market price per share (MPS) as the dependent variable (Y). The co-integration result reveals that there is a dynamic long-run association between the variables. The result of the ordinary least square indicates that Most of the variable except dividend per share had significant relationship with market price per share. The result also indicates that net asset per share, earnings per share and dividend per share has combined effect on market price of shares but none of these variables has direct independent influence in determining the price of market in the stock market.

Finally, the coefficient of determination (R2) is 0.912439 , which is approximately $91 \%$. This means that $91 \%$ of total variations in the value of market price per share (MPS) can be explained by changes in the values of the independent variables while the remaining $9 \%$ is due to other stochastic variables outside of the model. This paper therefore, concludes that dividend payout does not have effect on shareholders' wealth and shareholders do not react to dividend information.

\section{CONCLUSIONS}

The study investigates the effect of dividend policy on shareholders wealth in Nigeria between (1984 to 2014). The result of the study indicates that there is a dynamic long-run association between the variables. The result of the ordinary least square indicates that most of the variable except dividend per share had significant relationship with market price per share. The result also 
European Journal of Accounting, Auditing and Finance Research

Vol.8, No. 6, pp.15-27, May 2020

Published by ECRTD-UK

Print ISSN: 2053-4086(Print), Online ISSN: 2053-4094(Online)

indicates that net asset per share, earnings per share and dividend per share has combined effect on market price of shares but none of these variables has direct independent influence in determining the price of market in the stock market. This paper therefore, concludes that dividend payout does not have effect on shareholders' wealth and shareholders do not react to dividend information.

The findings of the study contradicts the works of Adelegan (2009), dividend policy matters and share prices do react to divided announcements; Okpara (2010a), dividend policy drives or granger causes information. Asymmetry and okpara (2010b), earnings, current ratio and previous year's dividends are goods Predictors of dividend payout policy in Nigeria.

Our findings suggest that Nigerian do not react to changes in the stock market; an indication that Nigerian capital market is a weak one (Adelegan 2009). As level of efficiency of stock market tend to influence the contributions of stock market to economic growth, this trend in the relationship between dividend and market price may discourage growth.

\section{Recommendations}

Based on these findings, this paper therefore recommends that firms operating under this environment should ignore the distribution of earning and concerned concentrate with investments that will boost net assets. The board of directors should review the dividend policy of the companies operating under this environment to ensure maximum operation. The firms should ensure that they comply with relevant and required dividend policy. The level of dividend payments should be determined by shareholders preference and implemented by their management representative.The firms operating under this environment should ensure the application of "shareholders value approach" to estimates the economic value of an investment by discounting forecasted cash flows by the cost of capital.

The accounting professional bodies should enforce standards on dividend policies of firm and ensure that it should be adhered to given the fact that directors of companies are responsible for making dividend decision. Organizations should ensure that they have a good and robust dividend policy in place. This will enhance their profitability and attract investments to the organizations. Directors of corporate organizations should be made to update the records of shareholders including their next-of-kin to avoid a deliberate diversion or undue retention of unclaimed dividend warrants. Due procedures for the recognition and utilization of profit arising from investment of unclaimed dividend should be effected and properly accounted for.

A more stringent level condition should be established to compel directors to only invest in profitable ventures, report the utilization of retention earnings through notes to the accounts.

\section{REFERENCE}

Agarwal R N (2014), "Dividends and Stock Prices: A Case Study of Commercial Vehicle Sector in India 1966-67 to 1986-87", Indian Journal of Finance and Research, Vol. 1, pp. 61-67.

Aivazian (2003), "Dividend policy and the organization of capital market", Journal Of Multinational Financial Management ,pp.101- 121 
European Journal of Accounting, Auditing and Finance Research

Vol.8, No. 6, pp.15-27, May 2020

Published by ECRTD-UK

Print ISSN: 2053-4086(Print), Online ISSN: 2053-4094(Online)

Aivazian, V, and Booth, L(2013), "Do emerging firms follow different dividend policies from US firms.?", Journal of Financial research, Vol.26 No.3,pp.371-87.

Allen Franklin and Michael Roni( 2013) ,Payout Policy, North-Holland handbook of Economics and Finance, Wharton Financial Institutions center.

Al-Malkawi, H (2013) "Determinant of Corporate Dividend Policy in Jordan", Journal of Economic and Administrative, vol. 23: 44-71

Asquith \& Mullins (2013), "The impact of initiating dividend payments on shareholders 'wealth", Journal of Business, Vol. 56, pp. 77-96.

Baker \& Garry (2012) ,"Determinants of corporate dividend policy: a survey of NYSE firms" , Financial Practice and education 9 ,pp29-40

Baker \& Veit (2001), "Factors influencing dividend policy decisions of Nasdaq firms", The Financial Review, pp 19-38

Bierman, Jr. H. (2011) Increasing Shareholder Value: Distribution Policy, a Corporate Challenge. Boston, MJ, Kluwer Academic Publishers

Black, Fischer, "The Dividend Puzzle", The Journal of Portfolio Management, winter 1976, pp.634-639.

Brown \& Warner (2012), "Measuring Security Price Performance”, Journal Frankfurter (2013) Dividend Policy Theory and Practice", Academic Press.

Fama \& French (2011) "Disappearing dividends: changing firm characteristics or lower propensity to pay?", Journal of Financial Economics, vol. 60: 3-43

Field, A. (2011) Discovering statistics: Using SPSS for Windows, London: Sage Publications

Foong, \& Tan (2014) "Firm Performance and Dividend-Related Factors: The Case of Malaysia", Labuan Bulletin of International Business \& Finance, vol. 5: 97-111

Frankfurter \& Wood (2002) "Dividend Policy Theories and Their Empirical Tests", International Review of Financial Analysis, vol. 11: 111-138

Grullon \& Michaely (2012) "Dividends, share repurchase and the substitution hypothesis", Journal of Finance, vol. 57: 1649-1684

Gugler \&Yurtoglu (2013) "Corporate governance and dividend pay-out policy in Germany", working paper, University of Vienna

Hafeez \& Attiya (2009) "The Determinants of Dividend Policy in Pakistan", International Research Journal of Finance Economics, vol. 25: 148-171

Holderness \& Sheehan (2013) "Dividend and Dominant Shareholders", working paper, Rochester University

Kevin, S (2013, Dividend Policy: An analysis of some determinants, Finance India, vol.6, No.2.

Kouki \& Guizani (2013) "Ownership Structure and Dividend Policy Evidence from the Tunisian Stock Market”, European Journal of Scientific Research, vol. 25, no. 1: 42-53

Kouki, M. (2012) "Corporate Dividend behavior: a case study of firms listed with Tunisian stock market", Euro-Mediterranean Economics and Finance Review, vol.1, no. 1

Kumar, J. (2014) "Corporate Governance and Dividend Policy in India", Journal of Emerging Market Finance, vol. 5, no. 5: 15-58 Oaks, CA: Sage

Miller \& Modigliani (1961) "Dividend policy, growth, and the valuation of shares", Journal of Business, vol. 34: 411-433

Mohammed \& Joshua (2010), "Determinants of Dividend payout ratios in Ghana" , The Journal Of Risk Finance, Vol 7 No.2, pp136-145 
European Journal of Accounting, Auditing and Finance Research

Vol.8, No. 6, pp.15-27, May 2020 Published by ECRTD-UK

Print ISSN: 2053-4086(Print), Online ISSN: 2053-4094(Online)

Nissim \& Ziv (2001) “Dividend changes and future profitability”, Journal of Finance, vol. 56 (6): 2111-2133

Ross \& Westerfield (2012) Corporate Finance (6th ed.), McGraw-Hill Companies

Samuel \& Edward (2011) "Dividend Policy and Bank Performance in Ghana", International Journal of Economics and Finance, vol. 3, no. 4, doi:10.5539/ijef.v3n4p202 